\title{
RELATIONSHIP BETWEEN KNOWLEDGE AND EXPERIENCE OF WORKING JOURNALISTS
}

\author{
Yamna Sabir \\ Government College University Faisalabad, Pakistan
}

\begin{abstract}
In this research paper the relationship between the knowledge and experience of working journalists has been identified in Faisalabad (The third most populated city of Pakistan). Purposive sampling technique was used to access the Journalist of various news channels and news papers of this region. The salary, number of news items being produced in a day, terms of employment, kind of beat assigned to the journalist, addition of their own views, perception about utility of experience or knowledge in their routine work were analyzed. Data was collected by using questionnaire and a knowledge evaluating tests in order to make a comparison between their working and acquaintance. General findings of the study were that any lacking in one field directly pulled back the performance in other one.
\end{abstract}

Keywords: working journalists, journalists beat, working experience

\section{Introduction}

The study has been conducted in Faisalabad which is the third most populated city of Pakistan. Faisalabad is the third biggest city in Pakistan with an expected 2006 populace of 2.6 million (city legitimate). The whole locale had a populace of around 5.4 million in 1998. Faisalabad city-area some time ago contained six sub-divisions; Faisalabad City, Faisalabad Sadr, Chak Jhumra, Jaranwala, Samundri, and Tandlianwala. In 2005, Faisalabad was rearranged as a City-Locale made out of eight self-governing towns, yet there are likewise a few informal neighborhoods frequently considered as towns. (YumYum)

As there were fewer channels the people in Faisalabad used to watch the one and only channel that was Pakistan television (PTV) to get themselves updated from their surrounding and the society.

Pakistan entered the TV broadcasting age in 1964, with a pilot TV channel set up at Lahore. This is the scene from which Pakistan's first transmission was broadcast in dark and white on the memorable date: 26th November, 1964.

The Rawalpindi Center was included 1967 and Peshawar and Quetta Focuses included 1974.The National Telecaster has thrived from that point forward, and today has PTV-Focuses in Islamabad, Lahore, Karachi, Peshawar, Quetta, Muzafarabad, AJK and Multan while the PTV Home office is additionally situated in Islamabad, the Government Capital.

At the point when PTV appeared in 1964, there was a staff of 30 workers, which has now ascended to more than 6000 people at all Units of the Organization. The representatives of PTV are partitioned into 09 groups and each group has a different pay scale. (Pakistan Television Co-Operation)

Journalism was new to everyone when it came in early ages and there were very few people in this field as it was not so popular. The occupation of the journalists was considered as a low quality work because masses lack experience and knowledge. It was not known how to present in front of the public similarly the audience were also unaware to express their thoughts and wishes that what were their actual desires to watch on media due to this journalists felt it arduous to work on screens. Print media was famous that time and it had more impact on people because it was cheap and easily access able. There was no trend of electronic media as it is on its peak in 
present era. Due to the lack of knowledge and experience it seemed difficult for the working journalists to make fair decisions as the media studies were very rare and very less number of institutions offered professional studies in media.

There was no proper coverage to the important events and none of the issues were highlighted seriously as there were very less channels therefore, it was very tough to grip on uncertain situations. On the base of less experience and knowledge, journalists used to deliver news and write a very few columns only. The journalism was known as so-called career that time and the would be novelists were supposed to write for the newspapers and magazines for their earning process.

In the early and present era, relationship of knowledge and experience for the working journalists have a very strong bonding, both are incomplete without each other's chemistry. If a journalist lack knowledge, he has no grip on the information and he is unable to make proper sentences and if he lacks experience, he is unable to present his knowledge in front of others so without both of these elements, a working journalist is inappropriate for the professional field and hence, he is not assumed to be called a journalist.

Press flexibility has never been steady in Pakistan. Distinctive administrations utilized lawful and protected intends to control the press from open level headed discussion and feedback. In it sixty years of history, Pakistan has been managed by military more than the regular citizen. Press in Pakistan for the most part confronts dangers, savagery, financial weight, and so forth. The nation's law on lewdness has been utilized against columnists. Poor education, urban introduction of the press, and the high cost of daily papers are impeding variables for the a work in progress of print media in Pakistan . Close to these blockades, one can now effortlessly see a move from the brought together communicating to an open rivalry communicate framework in Pakistan, empowering the gathering of people to appreciate more energy of particular presentation. (Siraj)

The Pakistani media is an eager individual from the new warrior family of the 21 st century and regardless of having a place with war-torn nation, is assuming dynamic part with regards to the requests of the present day times. Via airing dissimilar perspectives and taking part in cross addressing on noteworthy national and social issues the media reflects and illuminates general sentiment and basically shares the errand of the parliament. Investigative revealing and live talks can undermine the spell of numerous a performers.

This has encouraged community to the until now concealed workings of the political and bureaucratic set-up while at the same time highlighting the shameful acts endured by the regular man accordingly of the shady practices of the first class.

After a critical part of media in reestablishing the legal emergency, media has a remarkable capacity to go about as an impetus in common society endeavors to fortify popularity based commonwealth.

The principal fixing making vote based system conceivable is the stream of data. The media (plural of medium )electronic, print, digital and web guarantees this stream of data. In the event that confined, edited or obstructed in any capacity the general population will stay unmindful, oblivious of occasions, uninformed of their rights, their obligation to the Express, their requirements and the part that they can play for the advancement of the general public they live in and the nation overall.

Macaulay called the Press as Fourth Home of the legislature, yet the coming of innovation the media has increased new measurement, incredible quality and sharp changing the present age into data blast.

The media assumes a critical part in transmitting the cases of social, monetary and political developments to the chiefs and people in general. A free press and electronic media is a fundamental quality today of a popularity based country on the grounds that exclusive these wellsprings of data can keep data streaming unreservedly as well as help keep up a consistent exchange between the approach producers and the masses. (Media in Pakistan , 2007) 
Journalists, similar to researchers, figure information by sewing realities to settings. They require logical and basic and also story aptitudes and substantive information. The naturally half and half nature of news coverage — its reliance on both solid abilities and more extensive scholarly learning — can't be settled in theory; subject information and viable aptitudes will dependably mutually influence the nature of announcing, similarly as they together influence the nature of instructing.

What, then, can writers realize in a scholastic setting, and when and by what method ought to such review join with or respect the real routine with regards to news-casting? The primary question is the simpler one: Journalists ought to study whatever conveys profundity and modernity to their work; without making one wonder, that could be nearly anything. A few types of news coverage require generalists, others request ability; specialization or skill is the thing that college grounds best give at the graduate level, similarly as they give general expansiveness to students. Columbia's lord of expressions program means to do that through its four ranges of focus, yet why restrain it to those? Why not offer, for instance, a news-casting track with a fixation in Arabic and Center Eastern reviews, or ecological science, or general wellbeing - or something else of journalistic significance?

Journalists everywhere throughout the world face various types of issue and circumstances. Since at times they are highlighting issues that influence persuasive individuals picture. That is the reason they are debilitated and confront stubbornness. In this circumstance an extremely solid system and spunk is required. Understudies who are examining news coverage are somewhat startled of this calling. What's more, some abstain from joining this calling on account of its picture and a few cases in which writers are slaughtered by the adversaries. Grapples, news casters, climate forecasters, host of various diverts have taken degrees in news coverage yet they are not under red line. Correspondents and investigative columnists are for the most part the sufferer.

Journalists ought to must be mindful in passing on data to maintain a strategic distance from any terrible results. Infrequently they are additionally in rush to break the news without getting its legitimacy. Along these lines individuals quit putting stock in them. So dependably be patient and exchange it to others after affirmation. Columnists carry on with an elevated expectation life and they have joins with numerous critical and partnered individuals. Rich individuals are the ones who need to stay in contact with them. Some offer pay off to shroud their exercises. Be that as it may, I think a man of solid character dependably keep away from such offers and knows his/her rights and commitment. This calling is so respectable in light of the fact that they uncover terrible acts and make individuals mindful about what is happening around them. So dependably indicate both sides of the photo. So the country can choose well. Columnist and correspondents ought to abstain from being one-sided and distortions to keep up accept among the country. (Jabeen, 2015 )

\section{Objectives}

The objective of this study is to know that is knowledge or experience more important for working journalists. After this study, one can get a clear idea that which thing is more important and the factor of confusion regarding this phenomenon would be eliminated moreover, a clear image of the concept would be created after the completion of this article.

\section{Research questions}

- Are future writers being chosen on the base of information or experience?

- Does your boss enable your own particular convictions and considerations to impact your revealing?

- Do you feel that male and female columnists are dealt with similarly as far as pay? 


\section{Literature Review}

The knowledge is defined as the facts, information, and skills acquired through experience or education i.e. the theoretical or practical understanding of a subject where as Experience is defined as the knowledge or skill acquired by a period of practical experience of something, especially that gained in a particular profession. (Leif, 2014)

The working journalist performs different types of tasks, they work in different kinds of beats and areas in which they find and present various kinds of information. They perform different roles where needed and are also prepared to work as a reporter, anchor, sub-editor and photojournalists etc and each journalist have different experiences from one another which they have acquired from their lives and working careers as they visit places for the sake of information and due to this every working journalist thinks according to his own point of view and try to present the situation and solve an issue on the base of knowledge and experience he has gathered (Estate, 2008).

As there are different fields of media like electronic, print, social etc and for this purpose there are specific persons working professionally i.e. journalists and reporters. If a journalist covers TV programs and come live on the television every day in other words he is a journalist for electronic media then he won't be able to write as perfect as a journalist of print media so in this sense, gap occurs in the experiences therefore the one who works in electronic media can't compete with the other professional in the print media on the base of gaps in knowledge and experience in both the fields as both differs from each other and they will also definitely lack proper training and various professional practice of journalism programmes, (Dickson, 2000). Journalism is based on creativity of mind that how you tackle a situation and make its worth for talking on it and generating new ideas in order to cover a certain topic and highlight it among the society so in building innovative ideas to handle an issue and to discuss it in front of the whole world, knowledge alone is not useful because it doesn't helps in making connections between what we know. (Cooper, 2014). When Journalism was new.The journalists didn't have much knowledge and in the late nineteenth century, it was slowly being developed and its scope was not much because the people working in it didn't have much knowledge and experience regarding it, even they were not able to cover the events properly as they lack the most important things i.e. knowledge and experience the situation in all types of media was fetal there were no professionals to work in the field and journalism was only thought as a so-called field to work in. (Young,2012)

In the present era a journalist is useless if he doesn't have grip on knowledge and experience as the knowledge is the base and experience is the key to make it reach the heights. Even in the academic career a journalist is chosen on the basis of both these things even if a person has passed with highest scores but if he doesn't know to express his knowledge then he is not capable for coming in the professional field. There are certain skills on the base of which, a working journalist could be called an experienced and knowledgeable journalist, these skills are very important for the people working in this field and even for the students of Journalism to be selected in the field in future, these skills include reporting and covering a beat, interviewing personalities and gathering sources for the collection of data and must have knowledge about ethics and media laws. (The Changing Newsroom , 2009). Accurate decision making is very important in every field and in the field of journalism, it's really important to make decisions in order to make reports and on airing them according to the ethics and laws on media on the base of experience that journalists get from their work, they are able to make more fair decisions in different uncertain situations.

At the time when Journalism was new, reporting was thought everything in this field and the stories were constructed on the base of documents and other evidences but now in the present era, experience matters a lot and the stories are made on the base of observation and both by using knowledge and experience and most importantly spending time with the subject on which the journalist is going to report and all the facts are analyzed on the base on knowledge and experience. (Adam)

Knowledge along with experience is very important because the practical skills are very compulsory for performing better in the field if one would have better experience for working in the field, he would have better 
reporting skills too. Knowledge and experience, both when combined together affects the quality of reporting as well as the field work. (Scheuer, 2007).

\section{Methodology}

Different news channels were surveyed, and questionnaires were delivered to the working journalists in Abb Takk, Neo and different channels and the sample of 50 working journalists was taken and indepth interviews were conducted regarding this study and the sampling technique used was Available sampling/convenience sampling and purposive sampling. The working journalists filled the questionnaires and the collected data was entered in to the software named SPSS after that to analyze the data frequencies tables of gender, age and education were made and co-relation was applied on different questions to get reliable and satisfied results.

\section{Analysis and discussion}

This chapter puts forth the analysis of the data collected and discusses the outcome.

Frequency tables of Gender, Age and Education.

Table 1 Frequency and percentage of gender wise data

\begin{tabular}{|c|c|c|c|c|c|}
\hline & & Frequency & Percent & Valid Percent & $\begin{array}{l}\text { Cumulative } \\
\text { Percent }\end{array}$ \\
\hline \multirow{3}{*}{ Valid } & Female & 8 & 16.0 & 16.0 & 16.0 \\
\hline & Male & 42 & 84.0 & 84.0 & 100.0 \\
\hline & Total & 50 & 100.0 & 100.0 & \\
\hline
\end{tabular}

This table 1 shows that out of total of 50 journalists, eight were females and 42 males

Table 2: Frequency and percentage of age group

\begin{tabular}{|c|c|c|c|c|c|}
\hline & & Frequency & Percent & Valid Percent & $\begin{array}{c}\text { Cumulative } \\
\text { Percent }\end{array}$ \\
\hline & 18 to 24 & 26 & 52.0 & 52.0 & 52.0 \\
\hline & 25 to 34 & 19 & 38.0 & 38.0 & 90.0 \\
\hline & 35 to 44 & 5 & 10.0 & 10.0 & 100.0 \\
\hline & Total & 50 & 100.0 & 100.0 & \\
\hline
\end{tabular}


Table 2 shows that from the sample of 50 working Journalists from different news channels, there were 26 persons in the age group of 18 to 24, in the age group of 25 to 34 there were 19 persons and only 5 persons were there in the age group of 35 to 44 .

Table 3: Frequency and percentage of Education level of the respondents

\begin{tabular}{|c|c|c|c|c|c|}
\hline & & Frequency & Percent & Valid Percent & $\begin{array}{c}\text { Cumulative } \\
\text { Percent }\end{array}$ \\
\hline \multirow{5}{*}{ Valid } & Matric & 1 & 2.0 & 2.0 & 2.0 \\
\hline & $\mathrm{FA} / \mathrm{FSc}$ & 3 & 6.0 & 6.0 & 8.0 \\
\hline & $\mathrm{BA} / \mathrm{BSc}$ & 34 & 68.0 & 68.0 & 76.0 \\
\hline & MA/MSc & 12 & 24.0 & 24.0 & 100.0 \\
\hline & Total & 50 & 100.0 & 100.0 & \\
\hline
\end{tabular}

Table 3 shows that in the sample of 50 working journalists, there was only one person whose education was Matric, 3 persons who did intermediate and 34 persons were there whose education was Graduation and there were only 12 persons who did masters in different fields of study mentioned in the questionnaires.

Table 4: Frequency and percentage of equal treatment of female and male journalists in terms of salary

\begin{tabular}{|l|r|r|r|r|}
\hline & Frequency & Percent & Valid Percent & $\begin{array}{c}\text { Cumulative } \\
\text { Percent }\end{array}$ \\
\hline Yes & 15 & 30.0 & 30.0 & 30.0 \\
& 21 & 42.0 & 42.0 & 72.0 \\
No & 13 & 26.0 & 26.0 & 98.0 \\
Valid Don't know & 1 & 2.0 & 2.0 & 100.0 \\
$\quad$ Refuse to answer & 50 & 100.0 & 100.0 & \\
Total & & &
\end{tabular}

Table 4 shows that 15 individuals answered this question as Yes, 21 individuals disagreed with it, 13 people don't know about it and only 1 person refused to answer it among the total number of 50 individuals.

Table 4 shows that 15 individuals answered this question as Yes, 21 individuals disagreed with it, 13 people don't know about it and only 1 person refused to answer it among the total number of 50 individuals. 


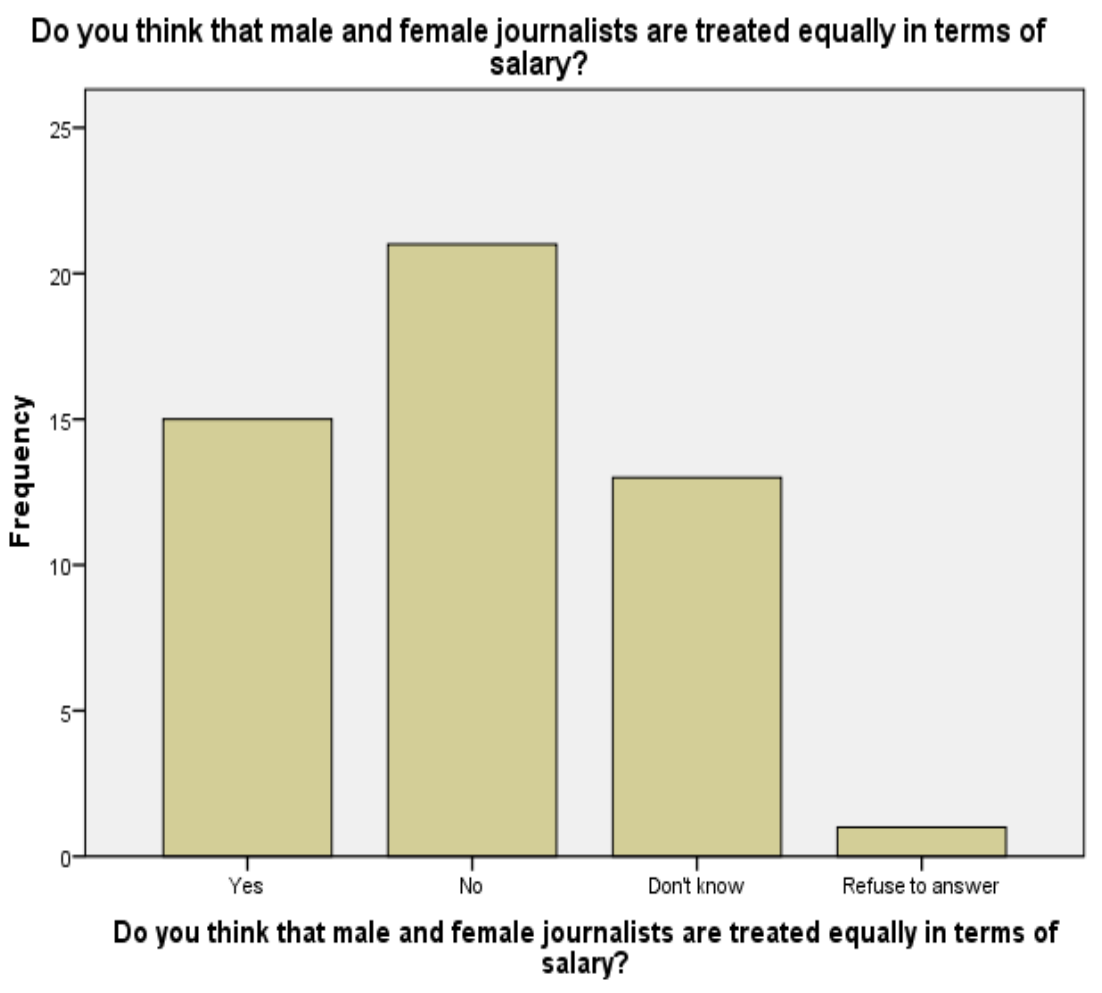

Table 4 shows that 15 individuals answered this question as Yes, 21 individuals disagreed with it, 13 people don't know about it and only 1 person refused to answer it among the total number of 50 individuals.

Table 5: Frequency and percentage of the following of ethics and laws by the journalists

\begin{tabular}{|l|r|r|r|r|}
\hline & Frequency & Percent & Valid Percent & $\begin{array}{c}\text { Cumulative } \\
\text { Percent }\end{array}$ \\
\hline Yes & 8 & 16.0 & 16.0 & 16.0 \\
No & 14 & 28.0 & 28.0 & 44.0 \\
Valid Some what & 27 & 54.0 & 54.0 & 98.0 \\
$\quad$ Refuse to answer & 1 & 2.0 & 2.0 & 100.0 \\
Total & 50 & 100.0 & 100.0 & \\
\hline
\end{tabular}




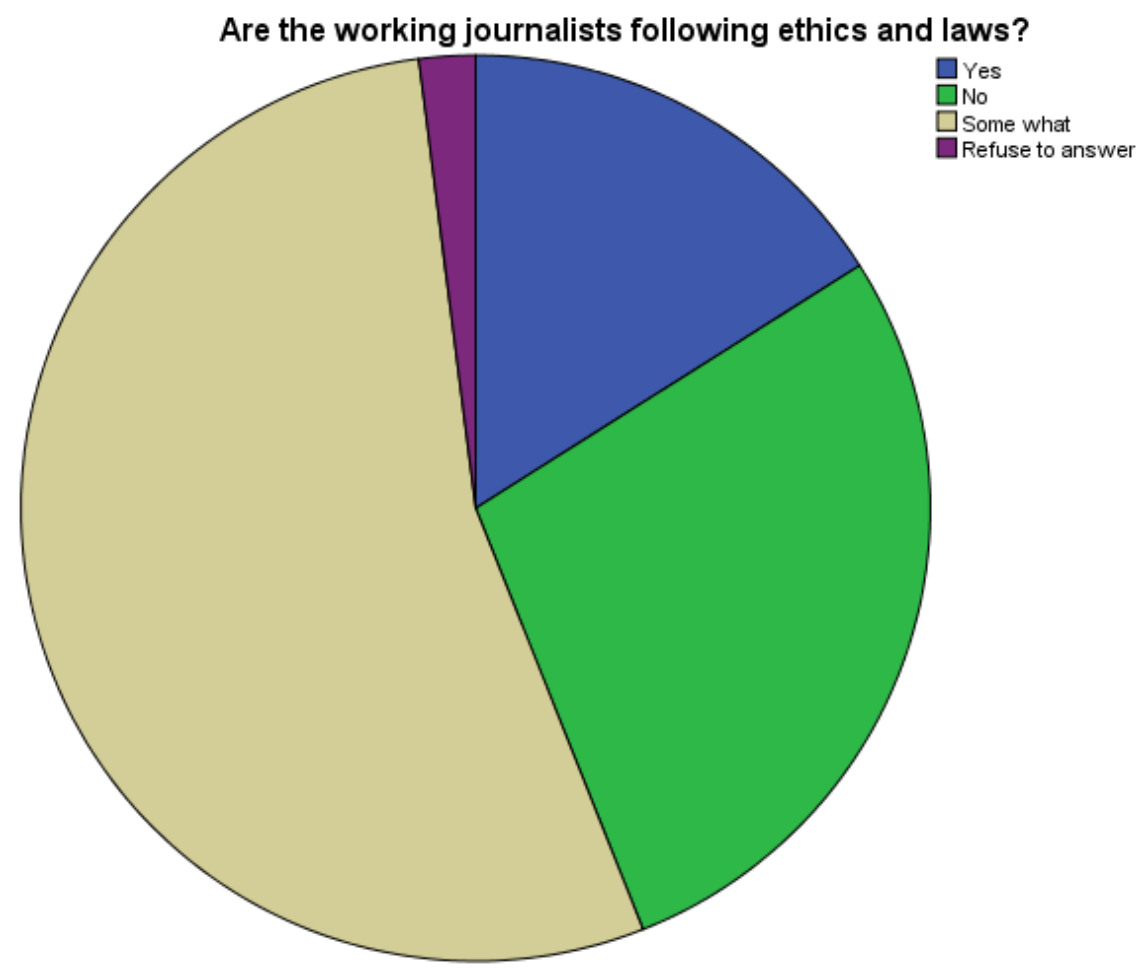

Table 5 shows that 8 individuals agreed with the statement, 14 answered No, 27 individuals answered Some What and 1 person refused to answer that working journalists follow ethics and laws among a total number of 50 working Journalists.

Table 6: Frequency and percentage of the selection of future journalists on the base of knowledge or experience

\begin{tabular}{|c|c|c|c|c|c|}
\hline & & Frequency & Percent & Valid Percent & $\begin{array}{c}\text { Cumulative } \\
\text { Percent }\end{array}$ \\
\hline \multirow{5}{*}{ Valid } & Knowledge & 4 & 8.0 & 8.0 & 8.0 \\
\hline & Experience & 9 & 18.0 & 18.0 & 26.0 \\
\hline & Both & 36 & 72.0 & 72.0 & 98.0 \\
\hline & Both not & 1 & 2.0 & 2.0 & 100.0 \\
\hline & Total & 50 & 100.0 & 100.0 & \\
\hline
\end{tabular}

Table 6 shows that 4 of the individuals answered Knowledge, 9 answered experience, 36 individuals answered Both and only a single person answered Both not of the question that on what basis future Journalists are being selected from a total number of 50 working Journalists.

After applying co-relation on these two questions, the value comes -0.071 . The value is Negative hence, it slightly co-relate in the Negative sense. 
The value 0.219 comes after applying co-relation on these two questions, the value is Positive. Hence, it tells that there is moderate co-relation between these two statements in Positive Sense.

Since how long you (working journalists) have been working?

Does your employer allow your (working journalists) own beliefs and thoughts to influence your reporting?

Correlations

\begin{tabular}{|c|c|c|c|}
\hline & & $\begin{array}{l}\text { Since how long you } \\
\text { (working journalists) } \\
\text { have been working? }\end{array}$ & $\begin{array}{l}\text { Does your (working } \\
\text { journalists) employer } \\
\text { allow your own beliefs } \\
\text { and thoughts to } \\
\text { influence your } \\
\text { reporting? }\end{array}$ \\
\hline $\begin{array}{l}\text { Since how long you (working } \\
\text { journalists) have been working? } \\
\text { Does your employer allow your } \\
\text { (working journalists) own beliefs and } \\
\text { thoughts to influence your reporting? }\end{array}$ & $\begin{array}{c}\text { Pearson Correlation } \\
\text { Sig. (1-tailed) } \\
\text { N } \\
\text { Pearson Correlation } \\
\text { Sig. (1-tailed) } \\
\text { N }\end{array}$ & $\begin{array}{c}1 \\
\\
\\
50 \\
.219 \\
.063 \\
50\end{array}$ & $\begin{array}{c}.219 \\
.063 \\
50 \\
1 \\
\\
50\end{array}$ \\
\hline
\end{tabular}

\section{Correlations}

\begin{tabular}{|c|c|c|c|}
\hline & & $\begin{array}{c}\text { What are the terms of } \\
\text { your employment? }\end{array}$ & $\begin{array}{l}\text { Does your employer } \\
\text { allow your own beliefs } \\
\text { and thoughts to } \\
\text { influence your } \\
\text { reporting? }\end{array}$ \\
\hline $\begin{array}{l}\text { What are the terms of your } \\
\text { employment? } \\
\text { Does your employer allow your own } \\
\text { beliefs and thoughts influence your } \\
\text { reporting? }\end{array}$ & $\begin{array}{c}\text { Pearson Correlation } \\
\text { Sig. (1-tailed) } \\
\mathrm{N} \\
\text { Pearson Correlation } \\
\text { Sig. (1-tailed) } \\
\mathrm{N}\end{array}$ & $\begin{array}{c}1 \\
\\
50 \\
-.071 \\
.312 \\
50\end{array}$ & $\begin{array}{c}-.071 \\
.312 \\
50 \\
1 \\
50\end{array}$ \\
\hline
\end{tabular}

\section{Conclusion}

After the collection of data for the article on which the study was made tell the views of the working journalists from different channels the sample taken was of 50 individual working journalists who age their point of view about this topic i.e. Relation between the knowledge and experience of working journalists. Most of them gave their final answer that both the knowledge and experience matter in the field of journalism and they were quiet satisfied with their given answers. The frequency tables of Age, Gender, Education and some questions were made while on other pair of questions, correlation was applied and in some, bar charts and pie charts were made too, to represent the question's results like the frequency table of the question that the "future journalists are selected on the base of knowledge or experience", tells that 36 individuals answered it that journalists are selected on the base of knowledge and experience, this answer could be considered as reliable because the majority goes with it similarly, in the question. "Do you think that male and female journalists are treated 
equally in terms of salary" 21 individuals disagreed with it only 15 of them agreed with it, it tells that the individuals were unable to be satisfied with their salary as compared to females. While applying the correlation on a pair of question, these questions were "Since how long you (working journalists) have been working? And How many news items do you (working journalists) produce/process in a day?" these two questions highly correlation with each other that the working period do effect the news items of a working journalist that he produce in a day as the value of correlation comes 0.618 which describe itself clearly. Therefore, the overall result comes that the relationship between the knowledge and experience of working journalists is quite strong and in future, both of these things are being followed for the selection of a working journalist.

\section{Limitations}

The data regarding this research cannot be generalized as it is only limited to the Urdu News papers and the Urdu TV channels as it was told before that 50 working journalists were taken from different channels and newspapers of Faisalabad.

\section{Suggestions}

It is suggested about the study that more research could be done on national and international media.

English and regional press should be included in the study and the study could be more vast including the more number working journalists from different news and tv channels all around the globe.

\section{References}

Adam, G. S. (n.d.). Journalism Knowledge and Journalism Practice. 9-11.

Cooper, B. B. (2014, May 2). Life Hacker. Retrieved 2016, from http://lifehacker.com/the-difference-betweenknowledge-and-experience-1516486966

Dickson, T. B. (2000). The Gap between Educators and Professional Journalists. Journalism and Mass Communication Educator , 50-67.

Estate, D. I. (2008). Retrieved June 2016, from The News Manual.

Jabeen, F. (September 15, 2015 ). Journalism In Pakistan.

Leif. (2014, March 2nd). Retrieved June 2016, from English Stackexchange: http://english.stackexchange.com/questions/154769/differences-between-knowledge-and-experience

Media in Pakistan . (2007). Retrieved from http://www.cssforum.com.pk/css-compulsorysubjects/essay/essays/32892-media-pakistan.html

Pakistan Television Co-Operation. (n.d.). Retrieved May 20, 2017

Scheuer, J. (2007, September 15). Journalism and Academia: How They Can Work Together. Retrieved 2016, from Neiman Reports : http://niemanreports.org/articles/journalism-and-academia-how-they-can-work-together/

Siraj, S. A. (n.d.). CRITICAL ANALYSIS OF PRESS FREEDOM IN PAKISTAN. Global Media Journal .

The Changing Newsroom . (2009, January 29). Retrieved 2016, from changing newsroom wordpress: https://changingnewsroom.wordpress.com/2009/01/29/skills-and-knowledge-every-journalism-student-needs/

YumYum. (n.d.). faisalabad4u.blogspot.com. Retrieved May 20, 2017 


\section{Questionnaire}

Name:

Gender:

Age:

Degree:

1. What is the title of your job?
a) TV Reporter
b) Journalist
c) Newscaster
d) Other

2. What are the terms of your employment?
a) Full-Time employee
b) Part-Time employee
c) Freelancer
d) Other

3. What kind of beat you work on?
a) Political
b) Crime
c) Education
d) Other

4. Since how long you have been working?
a) 3-6 months
b) 7-8 months
c) 1-5 years
d) more than 5 years

5. How many news items do you produce/process in a day?
a) 2 packages
b) 3 packages
c) 5 packages
d) more than 5 packages

6. Which sources you use to collect data for news?
a) Search Engines
b) News Channels
c) Social Media
d) Other

7. What is the role of the journalist?
a) To be an absolutely detached observer
b) To act as watchdog of the Government

c) To set political agenda

d) To aware of ongoing situation

8. Does your employer allow your own beliefs and thoughts to influence your reporting?
a) Yes, he does
b) No, he doesn't
c) To some extent
d) Refuse to answer

9. Do you stay away from the information that can't be verified?
a) Yes, I always do so
b) I sometimes do so
c) No, I don't
d) I use information as it is

10. Do you think that male and female journalists are treated equally in terms of salary?
a) Yes
b) No
c) Don't know
d) Refuse to answer

11. Is experience or knowledge more important for working journalists?
a) Experience
b) Knowledge
c) Both
d) Both not

12. Are the working journalists following ethics and laws?
a) Yes
b) $\mathrm{No}$
c) Somewhat
d) Refuse to answer 
Yamna Sabir / Relationship Between Knowledge And Experience......

13. Are the journalists being respected in society in present era?
a) Yes
b) No
c) Somewhat
d) Refuse to answer

14. Are the important issues being given proper coverage?
a) Yes
b) $\mathrm{No}$
c) Somewhat
d) Refuse to answer

15. Future Journalists are being selected on the base of knowledge or experience?
a) Knowledge
b) Experience
c) Both
d) Both not 